Portland State University

PDXScholar

\title{
Effects of Management for Productivity on Adult Survival of Snowy Plovers
}

\author{
Eleanor P. Gaines \\ Portland State University, egaines@pdx.edu \\ Stephen J. Dinsmore \\ lowa State University \\ Michael T. Murphy \\ Portland State University, murphym@pdx.edu
}

Follow this and additional works at: https://pdxscholar.library.pdx.edu/bio_fac

Part of the Biology Commons, and the Ornithology Commons

Let us know how access to this document benefits you.

\section{Citation Details}

Published as: Gaines, E. P., Dinsmore, S. J., \& Murphy, M. T. (2020). Effects of management for productivity on adult survival of Snowy Plovers. Journal of Field Ornithology.

This Post-Print is brought to you for free and open access. It has been accepted for inclusion in Biology Faculty Publications and Presentations by an authorized administrator of PDXScholar. Please contact us if we can make this document more accessible: pdxscholar@pdx.edu. 
LRH: E. P. Gaines et al.

RRH: Survival of Adult Snowy Plovers

Proofs to Eleanor Gaines: egaines@pdx.edu

\title{
Effects of management for productivity on adult survival of Snowy Plovers
}

\author{
Eleanor P. Gaines ${ }^{1,4}$, Stephen J. Dinsmore ${ }^{2}$, and Michael T. Murphy ${ }^{3}$
}

${ }^{1}$ Oregon Biodiversity Information Center - Institute for Natural Resources, Portland State University, Portland, Oregon 97207, USA

${ }^{2}$ Department of Natural Resource Ecology and Management, Iowa State University, Ames, Iowa 50011, USA

${ }^{3}$ Biology Department, Portland State University, Portland, Oregon 97207, USA

${ }^{4}$ Corresponding author. Email: egaines@pdx.edu 


\section{E. P. Gaines et al. \\ Survival of Adult Snowy Plovers}

Gaines - 2

ABSTRACT. Understanding the factors contributing to variation in demographic parameters and their influences on population growth is fundamental to effective conservation of small populations, but this information is often not available. Among shorebirds, population growth is generally most sensitive to changes in adult survival so understanding the factors affecting this vital rate is important. We used a long-term mark-re-sight dataset and Program MARK to examine the effect of management actions, initiated to improve nesting productivity, on adult survival of a threatened population of Snowy Plovers (Charadrius nivosus) in Oregon, USA. Apparent adult survival averaged $0.71 \pm 0.01$ (SE) but increased from 1990 to 2014. This increase coincided with a decline in use of protective nest exclosures, but initiation of lethal nest predator management. The unexpected apparent benefit to adult survival of removal of nest predators, and the negative effect of protective nest exclosures, highlight the importance of understanding how management practices at one life cycle stage may have unintended consequences at other life stages. Our 25-year analysis adds to our knowledge of an intensively managed, threatened species at the northern limit of its range, but, more importantly, knowledge of the negative effect of exclosure use and the positive effect of predator management on adult survival can help inform conservation of less well-studied species with similar life histories. Key words: adult apparent survival, Charadrius nivosus, long-term monitoring, nest exclosures, predator management 


\section{E. P. Gaines et al. \\ Survival of Adult Snowy Plovers}

Gaines - 3

Understanding how life history parameters influence population growth is crucial to effective conservation, but this information is often lacking for species with declining populations. Among birds generally (Sæther and Bakke 2000) and shorebirds in particular, population growth is most sensitive to adult survival (Sandercock 2003, Stahl and Oli 2006, Dinsmore et al. 2010), thus understanding how management affects this vital rate is key to effective stewardship of threatened populations. Avian conservation efforts often focus on improving nest success because it is easier to monitor and affect nest fates through management actions than adult or fledgling survival and dispersal (Lebreton et al.1992, Sillett and Holmes 2002). Without a clear understanding of how management at one life cycle stage (nesting productivity) affects subsequent stages (adult and juvenile survival), managers run the risk of supporting misguided approaches that yield unintended results and use limited resources ineffectively (Heppell et al. 1996, Johnson et al. 2010).

Shorebird populations are experiencing alarming global declines (International Wader Study Group 2003, Rosenberg et al. 2019), and management often aims to improve nest success and survival to fledging. Protective nest exclosures have been widely used to improve productivity of ground-nesting shorebirds (Deblinger et al. 1992, Estelle et al. 1996, English et al. 2017), although there are concerns that the benefit of increased productivity is offset by an increase in adult predation around exclosures (Hardy and Colwell 2008, Barber et al. 2010, Burns et al. 2013). Additionally, human-altered habitats often result in an increase in synanthropic native and non-native predators, and these human-subsidized predators can have an outsized effect on small prey populations. Lethal predator management has been used to improve 


\section{E. P. Gaines et al.}

Survival of Adult Snowy Plovers

Gaines - 4

productivity for a variety of shorebird species (Pauliny et al. 2008, Fletcher et al. 2010, Catlin et al. 2011), although such management does not always promote population growth (Neuman et al. 2004). Predator removal is expensive, time intensive, and often controversial, so documenting its effect on different life stages and the overall demographic response is important (Lavers et al. 2010, Smith et al. 2010). Information about the effect of these commonly used management actions on adult survival — the life stage that most affects population growth — is fundamental to conservation.

The Pacific Coast population of Western Snowy Plovers (Charadrius nivosus nivosus) occurs within $80 \mathrm{~km}$ of the Pacific Coast from Damon Point, Washington, USA to Bahia Magdalena, Baja California, Mexico (U. S. Fish and Wildlife Service 2007, Page et al. 2009), and is listed as threatened by the U. S. Fish and Wildlife Service (USFWS) because of poor productivity and low survival (U. S. Fish and Wildlife Service 1993, 2007). Limiting factors for this population include increasing predation (Neuman et al. 2004), human disturbance (Ruhlen et al. 2003, Lafferty et al. 2006), and habitat loss to development, exotic vegetation, and recreational use (Page and Stenzel 1981, U. S. Fish and Wildlife Service 2007, Muir and Colwell 2010). Along the Oregon coast, intensive and coordinated management to benefit Snowy Plovers have addressed all these limiting factors since 1990, and populations in Oregon have increased over the last 25 years (Table 1). However, managers need to know how their actions affect individual life stages to allow effective decision-making as populations approach recovery goals and funding is allocated to species of more immediate conservation need.

Estimates of adult Snowy Plover survival are available for populations in California (Stenzel et al. 2011, Colwell et al. 2013), but not for Oregon where plovers are near their 
E. P. Gaines et al.

Survival of Adult Snowy Plovers

Gaines - 5

northern range limits and environmental and management conditions differ from further south. Furthermore, vital rates often vary spatially and temporally, and effective conservation requires a thorough understanding of local population dynamics (Anders and Marshall 2005, McNew et al. 2012, Eberhart-Phillips and Colwell 2013). The Oregon population has been color-banded since 1990 and individuals exhibit high levels of site fidelity (Oregon Biodiversity Information Center, unpubl. data), presenting an opportunity to study the effects of management actions on adult survival. We examined the effects of temporal and environmental factors on Snowy Plover adult apparent survival. Attempts have been made to boost nesting productivity of the Oregon Snowy Plover population through the use of both nest exclosures and lethal predator removal, so we also tested for an effect of these management practices, intended to improve nesting productivity, on adult survival. 


\author{
E. P. Gaines et al. \\ Survival of Adult Snowy Plovers
}

Gaines - 6

\title{
METHODS
}

Study area. As part of a long-term monitoring project, we studied breeding Snowy Plovers from 1990 to 2014 at nine sites along the Oregon coast that encompassed all regularly occupied coastal sites in Oregon (Fig. 1). Sites varied in ownership, management, predation, and recreation pressures. The Oregon population is geographically remote, but occasional dispersal occurs between states (the nearest nesting sites to Oregon are $>220 \mathrm{~km}$ away). Occupied habitat covered $\sim 17.7 \mathrm{~km}^{2}$ along a $181 \mathrm{~km}$ section of the Oregon coast, and included habitat typical of nesting Snowy Plovers: open ocean beaches, ocean over-wash sites, sand dunes, and estuarine sand flats. Dunes were dominated by non-native, invasive European beachgrass (Ammophila arenaria), which over time has stabilized the naturally ephemeral dune system, resulting in densely vegetated, steep dunes that are unsuitable for plover nesting and provide cover for predators (Wiedemann 1984, Muir and Colwell 2010). Breeding season management for Snowy Plovers in Oregon is intensive and includes habitat restoration and maintenance, recreation restrictions, and an integrated predator management plan incorporating both lethal and non-lethal actions (Dinsmore et al. 2014).

Field methods. We began color banding adults and chicks in 1990 and, during most years, at least $80 \%$ of the adult population was banded (Table 1; Dinsmore et al. 2017). We recorded observations of banded adults during surveys conducted at least weekly from April through September annually. We recorded the sex of adults based on plumage and behavior (Page et al. 2009).

Initial management to counter increasing populations of human-subsidized predators included trash and carcass removal from nesting beaches, harassment of individual predators, 


\section{E. P. Gaines et al. \\ Survival of Adult Snowy Plovers}

Gaines - 7

and, beginning in 1990, installation of protective exclosures around some nests $(N=1204$;

Dinsmore et al. 2014). Most exclosures were 5 x 10-cm wire-mesh cages with a wire top and blueberry netting false top to reduce the threat to plovers if they hit the top of the exclosure. Exclosures have repeatedly been shown to improve nest success (Hardy and Colwell 2008, Dinsmore et al. 2014), but anecdotal observations by us and others of adults killed by predators at exclosures (Murphy et al. 2003, Neuman et al. 2004, Watts et al. 2012, Colwell et al. 2013), raised concerns that adult survival differs at exclosed and unexclosed nests. Further steps to reduce predation began in 2002 with implementation of an integrated predator management plan at Coos Bay North Spit, Bandon Beach, and New River (Fig. 1) that included lethal removal of plover predators (Dinsmore et al. 2017). In 2004, lethal predator management was extended to all nine sites and continued for the duration of the study. Predator management was conducted by USDA APHIS-Wildlife Services (WS) in coordination with the Recovery Unit 1 Snowy Plover Working Team, and primarily targeted nest and chick predators, including American Crows (Corvus brachyrhynchos), Common Ravens (Corvus corax), non-native red fox (Vulpes vulpes), and striped skunks (Mephitis mephitis). WS technicians removed predators with padded-jaw leghold traps, cage traps, shooting, and chicken eggs tainted with the avicide DRC-1339. Nontarget predators were identified by WS technicians and Snowy Plover monitors based on tracks, nest camera data, and other evidence left at nests. Non-target predators were removed when their regular presence or hunting on a site posed a threat to plovers, and non-lethal control measures proved ineffective. Corvids comprised most removals (90\%), followed by red fox (5\%), striped skunk (2\%), and others (3\%) (Table 2). Predator management activities began before plover 


\section{E. P. Gaines et al.}

Survival of Adult Snowy Plovers

Gaines - 8

nesting (typically in February each year), continued through August, and were approximately equal across all sites.

Adult survival modeling. We compiled 25-occasion encounter histories for banded birds observed in Oregon as adults between 1990 and 2014 with a re-sighting period of 1 April to 31 July each year, a period of peak breeding and minimal movement. Most birds were documented nesting on our study area, and it is likely that we missed nests of other individuals. However, we acknowledge that the 120-day re-sight period may have included wintering or migrating individuals, contributing overdispersion to our sample. We used a live recaptures Cormack-JollySeber model in Program MARK (White and Burnham 1999) to generate maximum likelihood estimates of apparent annual survival $(\varphi)$ and detection probability $(p)$. We estimated apparent survival because limitations on existing data did not support an analysis of true survival, and thus our survival estimates should be considered minimums. Stenzel et al. (2011) documented high site fidelity ranging from $0.89-1.00$, dependent on sex and natal origin, in a true survival estimate for a similar Snowy Plover population at Monterey Bay. Our large re-sight area, high percentage of known breeders, and high site fidelity by Oregon plovers partially mitigate the confounding of permanent emigration with death (Nur et al. 1999, Sandercock et al. 2005, Stenzel et al. 2011, Maness and Anderson 2013); apparent survival of this population likely closely approximates true survival (Méndez et al. 2018).

We tested a fully time-dependent model $(\varphi[\mathrm{yr}] p[\mathrm{yr}])$ for goodness-of-fit using the median $\hat{c}$ procedure in MARK that indicated the data were slightly overdispersed, so we adjusted the variance inflation factor $(\hat{c})$ for all models to 1.21 . We used a hierarchical approach to model effects on detection probability first (no effect [.], year [yr], sex [sex], and linear [T] and 


\section{E. P. Gaines et al. \\ Survival of Adult Snowy Plovers}

Gaines - 9

quadratic [TT] time trends across years) with full year effects on survival. We used the most parsimonious model for detection probability to model effects on annual apparent survival (no effect [.], year [Yr], linear [T] and quadratic [TT] time trends across years, and sex [Sex]). After selecting a base survival model, we substituted annual covariates for winter weather conditions and management to see if these covariates better explained annual variation in adult survival. To avoid misleading results due to parameter collinearity, we did not include multiple time-related covariates in the same model (Maness and Anderson 2013). We included three potential sources of variation in adult survival in our models: winter weather, predator management, and exclosure use.

Winter weather. In a previous analysis, we found no effect of winter weather on juvenile survival, but Colwell et al. (2013) demonstrated that poor winter weather adversely affected annual adult survival in northern California. We thus hypothesized that poor winter weather might negatively affect adult survival and included three covariates to explore aspects of weather at multiple scales. Some plovers migrate to Washington or as far south as Baja California during the non-breeding season (Oregon Biodiversity Information Center, unpubl. data, Page et al. 2009). Thus, we included an annual covariate to reflect broad-scale climate conditions over the winter along the Pacific Coast. We used the sum of the monthly multivariate El Niño-Southern Oscillation indices (MEI) for September-March 1990-2014 (available from the National Oceanographic and Atmospheric Administration [NOAA] Earth System Research Laboratory Physical Sciences Division, https://www.esrl.noaa.gov/psd/enso/mei/) as a proxy for broad-scale regional winter climate conditions (Stenzel et al 2007, Wolter and Timlin 2011). 


\section{E. P. Gaines et al.}

Survival of Adult Snowy Plovers

Gaines - 10

Because many individuals remain in Oregon for the winter, we also explored local weather conditions by summing the number of colder-than-average (Cold) and wetter-thanaverage (Wet) days each winter along the Oregon coast. We obtained daily total precipitation and minimum temperature data from NOAA (Menne et al. 2012) collected between October and February each winter (winters of 1990-1991 to 2013-2014) at North Bend, Oregon Regional Airport (Station USW00024284, Fig. 1). We chose this site based on its central location in our study area and completeness of data during our study period. We identified cold winter weather (Cold) by summing the number of days each winter (October through February) that fell more than one standard deviation $\left(3.54^{\circ} \mathrm{C}\right)$ below the mean daily minimum winter temperature $\left(5.48^{\circ} \mathrm{C}\right)$ between 1990 and 2014 (i.e., $\left.<1.94^{\circ} \mathrm{C}\right)$. The number of colder-than-average days each winter ranged from seven to 38. Likewise, we identified wet winter weather (Wet) by summing the number of days each winter with precipitation more than one standard deviation $(1.17 \mathrm{~cm})$ above the mean daily precipitation $(0.66 \mathrm{~cm})$ over the same months and years (i.e., $1.83 \mathrm{~cm})$. The number of wetter-than-average days each winter ranged from five to 30 .

Predator management. Lethal predator management improved nest and chick survival to fledging in this population (Dinsmore et al. 2014, 2017). Although predator management primarily targeted nest and chick predators, we wondered if this survival benefit extended to adults. We explored the effect of years with and without lethal predator management on adult survival. There was no lethal predator management from 1990 to 2001. In 2002 and 2003, Coos Bay, Bandon, and New River received predator management and all sites had predator management from 2004 to 2014. We tested the predator management effect using two covariates for years with partial (2002 and 2003) and complete (2004 and later) predator management 


\section{E. P. Gaines et al.}

Survival of Adult Snowy Plovers

Gaines - 11

versus using a single covariate for years with any predator management (complete or partial). Results were similar, so we used only one covariate (PM) to code for any predator management from $2002-2014$ as this was more parsimonious.

Nest exclosures. Nest exclosures improved hatching success (Dinsmore et al. 2014), but we documented predation of multiple adults associated with exclosed nests and were concerned that birds nesting in exclosures may be subject to greater mortality. To determine if exclosures posed a threat to adult survival, we included a covariate for the percentage of known nests exclosed each year (EX). We hypothesized that adult survival would be lower in years with a high percentage of exclosure use.

We built all models using the design matrix and logit link function in Program MARK. We used an information-theoretic approach (Burnham and Anderson 2002) and model selection by Akaike’s Information Criterion (Akaike 1973) corrected for small sample size and overdispersion $\left(\mathrm{QAIC}_{c}\right)$ to identify the most parsimonious model among the suite of candidate models. We report on all competitive models within $7 \Delta \mathrm{QAIC}_{c}$ units of the model with the lowest QAIC $_{c}$ (Burnham and Anderson 2002), but removed models within 2 QAIC $c$ units that added a parameter without improving model deviance to ensure that $\Delta \mathrm{QAIC}_{c}$ values were not the result of uninformative parameters (Arnold 2010). We compared relative strength of support for each candidate model with evidence ratios of the QAIC ${ }_{c}$ weights (Burnham and Anderson 2002). We used the variance components procedure in Program MARK to calculate an overall estimate of survival including process variance, but not sampling variance. We report beta parameters and 95\% confidence intervals for specific model covariates, and establish significance if 95\% 


\section{E. P. Gaines et al.}

Survival of Adult Snowy Plovers

Gaines - 12

confidence intervals did not include zero. We report means \pm SE and 95\% confidence intervals for survival estimates, except where otherwise noted.

\section{RESULTS}

We monitored 1069 color-banded adults between 1990 and 2014. The number present and percent banded generally increased during our study (Table 1). Only 4\% of banded birds were initially banded outside of Oregon (as adults or chicks) and, of the rest, $73.5 \%$ and $22.5 \%$ were banded as chicks and adults, respectively. Our banded population included 571 males, 482 females, and 16 birds of unknown sex. We documented nesting in $83 \%$ of our population, but assume all individuals attempted nesting. We recorded 3006 live encounters, counting one resighting per individual per year between 1 April and 31 July annually.

Detection probability was best explained by a linear time trend and sex $(p(\mathrm{~T}+\mathrm{Sex}))$. Detection probability improved over time and was greater for males than females $(\beta$ sex $=0.33 \pm$ 0.16, CI: $0.02,0.63)$. Given the data, the top model for detection probability $\left(\mathrm{w}_{\mathrm{i}}=0.74\right)$ was more than three times as likely as the next best-supported model ( $\mathrm{w}_{\mathrm{i}}=0.22$, which differed only by dropping the covariate for sex) and, therefore, we subsequently used it for all survival models.

Our modeling results yielded four competitive models that we used to make inference about Snowy Plover adult survival in Oregon. Collectively, these four models had all support in the model set (Table 3). The best-supported model showed a positive linear trend in adult survival during our study $\left(\beta_{\mathrm{T}}=0.03 \pm 0.01, \mathrm{CI}: 0.02,0.05, \mathrm{w}_{\mathrm{i}}=0.48\right)$. Using this model, adult survival ranged from $0.61 \pm 0.03$ to $0.77 \pm 0.01$, and detection probability ranged from $0.89 \pm$ 0.03 to $0.98 \pm 0.01$, averaging $0.93 \pm 0.01$ for females and $0.96 \pm 0.00$ for males. Our best overall estimate of adult survival from 1990 to 2014 was $0.71 \pm 0.01$, calculated using the fully 


\section{E. P. Gaines et al.}

Survival of Adult Snowy Plovers

Gaines - 13

time dependent model and the variance components procedure in Program MARK. Models that substituted management effects for time were also well-supported. Adult survival was higher in years of lethal predator management $\left(\beta_{\mathrm{PM}}=0.40 \pm 0.10\right.$, CI: $\left.0.21,0.60\right)$; adult apparent survival was $0.66 \pm 0.02$ and $0.74 \pm 0.01$ in years without and with predator management, respectively. By contrast, annual adult survival declined as the proportion of exclosed nests increased $\left(\beta_{\mathrm{EX}}=-\right.$ $0.69 \pm 0.17$, CI: $-1.03,-0.35$; Fig. 2). Under this model, adult survival ranged from $0.65 \pm 0.02$ in 1999, a year when $87 \%$ of all known nests were exclosed, to $0.77 \pm 0.01$ in 2013 when we exclosed only $5 \%$ of nests. We also found a small, but significant, negative effect of wetter-thanaverage winter weather on adult survival $\left(\beta_{\text {Wet }}=-0.02 \pm 0.01\right.$, CI: $\left.-0.04,-0.01\right)$. However, adult apparent survival was unrelated to either cold weather or sex (95\% CI of coefficients included zero).

\section{DISCUSSION}

Our analysis suggests that management actions intended to improve nesting productivity had significant effects on adult survival. Given the limited resources available for recovery of declining species, directing efforts to where they will be most effective is important and, for long-lived species, understanding the basis for changes in adult survival is crucial for effective conservation. Management efforts often focus on improving productivity, because it is easier to monitor and improve through conservation actions than adult survival and dispersal (Lebreton et al.1992, Sillett and Holmes 2002). However, managers must also consider whether steps to improve productivity have negative downstream effects on other vital rates and population growth (Neuman et al. 2004, Barber et al. 2010, Calvert and Taylor 2011). 


\section{E. P. Gaines et al. \\ Survival of Adult Snowy Plovers}

Gaines - 14

Our overall estimate of adult apparent survival $(0.71 \pm 0.01)$ was similar to those reported from other Pacific Coast populations (Stenzel et al. 2007, Mullin et al. 2010, Stenzel et al. 2011, Colwell et al. 2013, Eberhart-Phillips et al. 2017). However, although estimates reported in other studies exhibited significant random variation from year to year, likely due to weather, our bestsupported model showed a positive linear trend in adult survival during our study. The management history of Snowy Plovers in Oregon confounds the effects of predator management, exclosure use, and time on adult survival, and limits our ability to explore interactions between these effects. However, the observed steady improvement in adult survival in the Oregon population over time, which cannot be explained by annual variation in weather (the most common cause for annual variation in survival [Colwell et al. 2013]), seems most parsimoniously explained by lethal predator management and reduced use of exclosures.

When human-subsidized predators use the same habitats as rare species, management must often control the subsidized species to maintain viable populations of the rare species (Boarman 2003, Martin et al. 2010). Predator management often results in improved productivity, but does not always lead to population growth (Neuman et al. 2004, Cote and Sutherland 1997, Lavers et al. 2010), although several studies report improved population viability with predator removal (Fletcher et al. 2010, Smith et al. 2010, Peery and Henry 2010). The lethal predator management program in Oregon was initiated to improve Snowy Plover nest and chick survival with positive results (Dinsmore et al. 2014, 2017). However, introduced fox and many of the non-target predators are documented predators of adult Snowy Plovers, and our analyses show that predator management improved survival across the life cycle. Lethal removal of nest predators may have increased adult survival directly through reduced predation on adults, 


\section{E. P. Gaines et al.}

Survival of Adult Snowy Plovers

Gaines - 15

or indirectly through improved nest and fledging success. Because Snowy Plovers renest readily after nest or brood failure, predator control may have reduced physiological costs to adults by allowing them to initiate and attend to fewer nests and broods to successfully fledge young (Nager 2006, Travers et al. 2010). This reduced reproductive effort may have led to increased adult survival. An alternative explanation, which we acknowledge, but find unlikely, is that the observed increase in adult survival after implementation of predator management was the result of lower permanent emigration due to higher nest success. Plovers will disperse when repeated nesting attempts are unsuccessful, but our large study area and their high breeding site fidelity argue against such an effect.

Many researchers have highlighted the need to weigh the benefit of increased productivity provided by exclosures against the potential cost of increased adult mortality (Neuman et al. 2004, Dinsmore et al. 2010, Calvert and Taylor 2011, Sim et al. 2011, Cohen et al. 2016). However, adult mortality is rarely observed, making it difficult to document the effects of exclosures. Early in our study, most nests were exclosed in an effort to improve nest success (Fig. 2, Dinsmore et al. 2014). However, we found 18 adults associated with exclosed nests depredated based on feathers or body parts in or near the exclosures. Roche et al. (2010) found that most apparent nest abandonment in Piping Plovers (C. melodus) was actually due to the death of adults and, in our study, an additional 27 exclosed nests were apparently abandoned during incubation or hatching and adults were never resighted, likely because they were depredated. If so, our results conservatively reflect predation on incubating adults. Although exclosed nests were monitored more closely, the fact that no adults associated with unexclosed nests were confirmed or suspected of being depredated suggests a potential serious threat to 


\section{E. P. Gaines et al.}

Survival of Adult Snowy Plovers

Gaines - 16

adults from exclosed nests. Because predator management resulted in improved nest success, we reduced exclosure use and our suspicion of negative effects of nest exclosures on adult survival was confirmed by our analysis. In Oregon, exclosures had a strong positive benefit on productivity (Dinsmore et al 2014), but, given the importance of adult survival to population growth, their benefits do not appear to outweigh the costs.

Decisions to use exclosures may go beyond direct effects on productivity or survival. For instance, we did not look for a direct negative effect of nesting in an exclosure on individual adult survival. Rather, we compared effects of exclosure use over years and found that adult survival was higher in years with less use of exclosures. Selective, low level use of exclosures may be beneficial. Snowy Plovers exhibit high fidelity to sites where they have successfully hatched eggs, although not necessarily to sites where they have fledged young (Pearson and Colwell 2014). Thus, by increasing the likelihood of eggs hatching, exclosures can help establish regular use of new sites. However, exclosures may also create an ecological trap if their use subjects adults to lower survival and encourages adults to repeatedly expend resources incubating eggs at sites with high rates of predation where they are unlikely to fledge young. 

E. P. Gaines et al.
Survival of Adult Snowy Plovers

Gaines - 17

Management implications. Snowy Plovers are a heavily managed threatened species, and effects of management on population growth are of immediate concern to conservation biologists. Without intensive management, the coastal Oregon plover population is likely to decline to an unsustainable size (U. S. Fish and Wildlife Service 2007). Adult survival is a key component of population growth, and our results suggest that lethal predator management, although initiated to benefit productivity, resulted in improved adult survival. Our results also suggest that use of exclosures had negative consequences for adult survival. Finally, we provide previously unavailable measures of adult survival from the northern edge of this species' distribution to help refine range-wide estimates of population viability that will be used in a future analysis to explore effects of exclosure use and predator management on overall population growth and viability. Our results can be generalized to species with similar life histories, but with little available demographic data, to make informed a priori predictions about the benefits of proposed management actions.

\section{ACKNOWLEDGMENTS}

Snowy Plover monitoring and management in Oregon is a cooperative effort funded by Coos Bay District Bureau of Land Management, Siuslaw National Forest, U.S. Fish and Wildlife Service, Oregon Department of Fish and Wildlife, and Oregon Parks and Recreation Department. USDA Wildlife Services conducted predator management activities. Monitoring work was initiated by Mark Stern and continued by the Institute for Natural Resources at Portland State University and Oregon State University. This work would not have been possible without the dedication of numerous field staff, particularly long-term plover biologists David Lauten, Kathleen Castelein, Daniel Farrar, and Adam Kotaich. We also appreciate the support of the 
E. P. Gaines et al.

Survival of Adult Snowy Plovers

Gaines - 18

Recovery Unit 1 Snowy Plover working team. Banding operations followed standard birdbanding techniques (Gustafson et al. 1997) and the Bander's Code of Ethics (U. S. Geologic Survey Bird Banding Laboratory 2011). Work was conducted under USFWS recovery permits TE839094 and TE39372B, USFWS banding permits 21825 and 23854, Oregon Department of Fish and Wildlife annual scientific take authorizations, Oregon State University (ACUP 3773), and Portland State University (PSU13.11.25.1 and 321 PSU10.07.27.1) Institutional Animal Care and Use permits. The authors declare no conflicts of interest. 
E. P. Gaines et al.

Survival of Adult Snowy Plovers

Gaines - 19

\section{LITERATURE CITED}

AKAIKE, H. 1973. Information theory and an extension of the maximum likelihood principle. In: Second international symposium on information theory (B. N. Petrov and F. Csaki, eds.), pp. 267-281. Akademiai Kiado, Budapest.

ANDERS, A. D., AND M. R. MARSHALL. 2005. Increasing the accuracy of productivity and survival estimates in assessing landbird population status. Conservation Biology 19:6674.

ARNOLD, T. W. 2010. Uninformative parameters and model selection using Akaike’s Information Criterion. Journal of Wildlife Management 74:1175-1178.

Barber, C., A. NowAK, K. TulK, AND L. ThOMAS. 2010. Predator exclosures enhance reproductive success but increase adult mortality of Piping Plovers (Charadrius melodus). Avian Conservation and Ecology 5:6.

BOARMAN, W. I. 2003. Managing a subsidized predator population: reducing Common Raven predation on desert tortoises. Environmental Management 32:205-217.

Burnham, K. P., AND D. R. Anderson. 2002. Model selection and multi-model inference, 2nd ed. Springer-Verlag, New York, NY.

Burns, F., N. MCCulloch, T. SzeKely, AND M. BoltON. 2013. No overall benefit of predator exclosure cages for the endangered St. Helena Plover Charadrius sanctaehelenae. Ibis 155:397-401.

Calvert, A. M., AND P. D. TAYLOR. 2011. Measuring conservation trade-offs: demographic models provide critical context to empirical studies. Avian Conservation and Ecology 6:2. 
E. P. Gaines et al.

Survival of Adult Snowy Plovers

Gaines - 20

CATLin, D. H., J. H. FELIO, AND J. D. FrASER. 2011. Effect of great-horned owl trapping on chick survival in Piping Plovers. Journal of Wildlife Management 75:458-462.

Cohen, J. B., A. Hecht, K. F. Robinson, E. E. Osnas, A. J. Tyre, C. Davis, A. KoceK, B.

MASLO, And S. M. MELVin. 2016. To exclose nests or not: structured decision making for the conservation of a threatened species. Ecosphere 7:e10499

Colwell, M. A., W. J. Pearson, L. J. Eberhart-Phillips, And S. J. Dinsmore. 2013. Apparent survival of Snowy Plovers (Charadrius nivosus) varies with reproductive effort and year between sexes. Auk 130:725-732.

CôTÉ, I. M., AND W. J. SUTHERLAND. 1997. The effectiveness of removing predators to protect bird populations. Conservation Biology 11:395-405.

Deblinger, R. D., J. J. VAske, And D. W. Rimmer. 1992. An evaluation of different predator exclosures used to protect Atlantic coast Piping Plover nests. Wildlife Society Bulletin 20:274-279.

Dinsmore, S. J., M. B. Wunder, V. J. DreitZ, And F. L. KnOpF. 2010. An assessment of factors affecting population growth of the Mountain Plover. Avian Conservation and Ecology $5: 5$.

Dinsmore, S. J., D. J. Lauten, K. A. Castelein, E. P. Gaines, And M. A. Stern. 2014. Predator exclosures, predator removal, and habitat improvement increase nest success of Snowy Plovers in Oregon, USA. Condor 116:619-628.

Dinsmore, S. J., E. P. Gaines, S. F. Pearson, D. J. Lauten, And K. A. Castelein. 2017. Factors affecting Snowy Plover chick survival in a managed population. Condor 119: 34-43. 
E. P. Gaines et al.

Survival of Adult Snowy Plovers

Gaines - 21

EBerhart-PhILliPS, L. J., AND M. A. COLWELl. 2013. Conservation challenges of a sink: the viability of an isolated population of the Snowy Plover. Bird Conservation International: $1-15$.

Eberhart-Phillips, L. J., C. KÜPper, T. E. X. Miller, M. CruZ-LÓPEZ, K. H. Maher, N. dos Remedios, M. A. StOfFel, J. I. Hoffman, O. KRÜGeR, AND T. SZÉKELy. 2017. Sexspecific early survival drives adult sex ratio bias in Snowy Plovers and impacts mating system and population growth. Proceedings of the National Academy of Sciences USA 114:E5474-E5481.

ENGLISH, W. B., E. KWON, B. K. SANDERCOCK, AND D. B. LANK. 2017. Effects of predator exclosures on nest survival of Red-necked Phalaropes. Wader Study 124:26-32.

Estelle, V. B., T. J. MABEe, AND A. H. FARMER. 1996. Effectiveness of predator exclosures for Pectoral Sandpiper nests in Alaska. Journal of Field Ornithology 67:447-452.

Fletcher, K., N. J. Aebischer, D. BAines, R. Foster, And A. N. Hoodless. 2010. Changes in breeding success and abundance of ground-nesting moorland birds in relation to the experimental deployment of legal predator control. Journal of Applied Ecology 47:263272.

Gustafson, M. E., J. Hildenbrand, And L. Metras [online]. 1997. Bird Banding Laboratory. North American bird banding manual. <http://www.pwrc.usgs.gov/BBL/manual/>. (20 January 2020).

Hardy, M. A., AND M. A. ColwELl. 2008. The impact of predator exclosures on Snowy Plover nesting success: a seven-year study. Wader Study Group Bulletin 115:161-166. 
E. P. Gaines et al.

Survival of Adult Snowy Plovers

Gaines - 22

Heppell, S. S., L. B. Crowder, And D. T. Crouse. 1996. Models to evaluate headstarting as a management tool for long-lived turtles. Ecological Applications 6:556-565.

INTERNATIONAL WADER STUDY GROUP. 2003. Waders are declining worldwide. Conclusions from the 2003 International Wader Study Group Conference, Cádiz, Spain. Wader Study Group Bulletin 101:8-12.

Johnson, H. E., L. S. Mills, T. R. Stephenson, And J. D. Wehausen. 2010. Population-specific vital rate contributions influence management of an endangered ungulate. Ecological Applications 20:1753-1765.

LAfFerty, K. D., D. GoOdman, AND C. P. SANDOVAL. 2006. Restoration of breeding by Snowy Plovers following protection from disturbance. Biodiversity \& Conservation 15:2217_ 2230.

LAVERS, J. L., C. WilCOX, AND C. J. DonlAN. 2010. Bird demographic responses to predator removal programs. Biological Invasions 12:3839-3859.

Lebreton, J.-D., K. P. Burnham, J. Clobert, And D. R. Anderson. 1992. Modeling survival and testing biological hypotheses using marked animals: a unified approach with case studies. Ecological Monographs 62:67-118.

MANESS, T. J., AND D. J. ANDERSON. 2013. Predictors of juvenile survival in birds. Ornithological Monographs 78:1-55.

Martin, J., A. F. O’Connell JR., W. L. Kendall, M. C. Runge, T. R. Simons, A. H. Waldstein, S. A. Schulte, S. J. Converse, G. W. Smith, T. Pinion, M. Rikard, And E. F. ZIPKIN. 2010. Optimal control of native predators. Biological Conservation 143:17511758. 
E. P. Gaines et al.

Survival of Adult Snowy Plovers

Gaines - 23

McNew L. B., A. J. Gregory, S. M. Wisely, And B. K. SAndercocK. 2012. Demography of Greater Prairie-Chickens: Regional variation in vital rates, sensitivity values, and population dynamics. Journal of Wildlife Management 76:987-1000.

MÉndez, V., J. A. Alves, J. A. Gill, And T. G. Gunnarsson. 2018. Patterns and processes in shorebird survival rates: a global review. Ibis 160: 723-741.

Menne, M. J., I. Durre, R. S. Vose, B. E. Gleason, And T. G. Houston. 2012. An overview of the Global Historical Climatology Network-Daily Database. Journal of Atmospheric and Oceanic Technology 29:897-910.

MuIR, J. J., AND M. A. COLWELL. 2010. Snowy Plovers select open habitats for courtship scrapes and nests. Condor 112:507-510.

Mullin, S. M., M. A. Colwell, S. E. McAllister, And S. J. Dinsmore. 2010. Apparent survival and population growth of Snowy Plovers in coastal Northern California. Journal of Wildlife Management 74:1792-1798.

Murphy, R. K., I. M. G. Michaud, D. R. C. Prescott, J. S. Ivan, B. J. Anderson, And M. L. French-Pombier. 2003. Predation on Adult Piping Plovers at predator exclosure cages. Waterbirds 26:150-155.

NAGER, R. G. 2006. The challenges of making eggs. Ardea 94:323-346.

Neuman, K. K., G. W. Page, L. E. Stenzel, J. C. WArriner, And J. S. WARriner. 2004. Effect of mammalian predator management on Snowy Plover breeding success. Waterbirds 27:257-263.

Nur, N., G. W. Page, And L. E. Stenzel [online]. 1999. Population viability analysis for Pacific Coast Snowy Plovers. 
E. P. Gaines et al.

Survival of Adult Snowy Plovers

Gaines - 24

<http://www.fws.gov/pacific/ecoservices/endangered/recovery/snowyplover/Appendix_D . pdf $>$ (20 January 2020).

Page, G. W., AND L. E. STEnzel. 1981. The breeding status of the Snowy Plover in California. Western Birds 12:1-40.

Page, G. W., L. E. Stenzel, J. C. WARriner, J. S. WARriner, And P. W. PATON. 2009. Snowy Plover (Charadrius alexandrinus). In:The Birds of North America Online (A. F. Poole, ed.). Cornell Lab of Ornithology, Ithaca, NY.

PAulinY, A., M. LARSSON, AND D. BlomQVist. 2008. Nest predation management: effects on reproductive success in endangered shorebirds. Journal of Wildlife Management 72:1579-1583.

PEARson, W. J., AND M. A. COLWELl. 2014. Effects of nest success and mate fidelity on breeding dispersal in a population of Snowy Plovers Charadrius nivosus. Bird Conservation International 24:342-353.

PeERy, M. Z. AND R. W. HenRy. 2010. Recovering marbled murrelets via corvid management: A population viability approach. Biological Conservation 143:2414-2424.

Roche, E. A., T. W. Arnold, And F. J. CuthBert. 2010. Apparent nest abandonment as evidence of breeding-season mortality in Great Lakes Piping Plovers (Charadrius melodus). Auk 127:402-410.

Rosenberg, K. V., A. M. Dokter, P. J. Blancher, J. R. Sauer, A. C. Smith, P. A. Smith, J. C. Stanton, A. Panjabi, L. Helft, M. Parr, And P. P. Marra. 2019. Decline of the North American avifauna. Science 366:120-124. 


\section{E. P. Gaines et al.}

Survival of Adult Snowy Plovers

Gaines - 25

Ruhlen, T. D., S. ABbott, L. E. STEnZel, AND G. W. PAGE. 2003. Evidence that human disturbance reduces Snowy Plover chick survival. Journal of Field Ornithology 74:300_ 304

SÆTHER, B.-E., AND Ø. BAKKE. 2000. Avian life history variation and contribution of demographic traits to the population growth rate. Ecology 81:642-653.

SANDERCOCK, B. K. 2003. Estimation of survival rates for wader populations: a review of markrecapture methods. Wader Study Group Bulletin 100:163-174.

SANDERCOCK, B. K., T. SzÉKELY, AND A. KoszTOLÁNYI. 2005. The effects of age and sex on the apparent survival of Kentish Plovers breeding in southern Turkey. Condor 107:583-596.

SiLlETt, T. S., AND R. T. HolmES. 2002. Variation in survivorship of a migratory songbird throughout its annual cycle. Journal of Animal Ecology 71:296-308.

Sim, I. M. W., G. W. Rebecca, S. C. LudWIG, M. C. Grant, AND J. M. Reid. 2011. Characterizing demographic variation and contributions to population growth rate in a declining population. Journal of Animal Ecology 80:159-170.

Smith, R. K., A. S. Pullin, G. B. Stewart, AND W. J. Sutherland. 2010. Effectiveness of predator removal for enhancing bird populations. Conservation Biology 24:820-829.

STAHL, J. T., AND M. K. OLI. 2006. Relative importance of avian life-history variables to population growth rate. Ecological Modelling 198:23-39.

Stenzel, L. E., G. W. Page, J. C. Warriner, J. S. WArriner, D. E. George, C. R. Eyster, B. A. RAMER, K. K. NEUMAN, AND B. K. SANDERCOCK. 2007. Survival and natal dispersal of juvenile Snowy Plovers (Charadrius alexandrinus) in central coastal California. Auk 124:1023-1036. 
E. P. Gaines et al.

Survival of Adult Snowy Plovers

Gaines - 26

Stenzel, L. E., G. W. Page, J. C. Warriner, J. S. Warriner, K. K. Neuman, D. E. George, C. R. Eyster, AND F. C. BIDSTRUP. 2011. Male-skewed adult sex ratio, survival, mating opportunity and annual productivity in the Snowy Plover Charadrius alexandrinus. Ibis 153:312-322.

Travers, M., M. Clinchy, L. Zanette, R. Boonstra, And T. D. Williams. 2010. Indirect predator effects on clutch size and the cost of egg production. Ecology Letters 13:980988.

U. S. Fish AND WILDLIFE SERVICE. 1993. Determination of Threatened Status for the Pacific Coast Population of the Western Snowy Plover. Federal Register 58:12864-12874.

U.S. Fish AND WiLdLIFE SERVICE. 2007. Recovery plan for the Pacific Coast Population of the Western Snowy Plover (Charadrius alexandrinus nivosus). U. S. Fish and Wildlife Service, Sacramento, CA.

U. S. GeOlOGiC Survey Bird BANDing LABOrAtory [ONLINE]. 2011. Banders’ code of ethics. Ethics and responsibility of bird banders.

<https://www.usgs.gov/centers/pwrc/science/ethics-and-responsibilities-bird-banders?qtscience_center_objects=0\#qt-science_center_objects $>$ (31 January 2020).

Watts, C. M., J. CaO, C. Panza, C. Dugaw, M. Colwell, and E. A. Burroughs. 2012. Modeling the effects of predator exclosures on a Western Snowy Plover population. Natural Resource Modeling 25:529-547.

White, G. C., AND K. P. BuRnhAM. 1999. Program MARK: survival estimation from populations of marked animals. Bird Study 46:S120-S139. 
E. P. Gaines et al.

Survival of Adult Snowy Plovers

Gaines - 27

Wiedemann, A. M. 1984. The ecology of Pacific Northwest coastal sand dunes: A community profile FWS/OBS-84/04. U. S. Fish and Wildlife Service, Washington, DC.

WOLTER, K., AND M. S. TIMLIN. 2011. El Niño/Southern Oscillation behaviour since 1871 as diagnosed in an extended multivariate ENSO index (MEI.ext). International Journal of Climatology 31:1074-1087. 
E. P. Gaines et al.

Survival of Adult Snowy Plovers

Gaines - 28

\section{TABLES AND FIGURES}

Table 1. Adult population estimates, percent of adult population banded, and percent of males in adult population of Snowy Plovers along the Oregon Coast, 1990 - 2014. For some years, the total population includes a small number of birds of unknown sex. From 1990 to 1992, field crews did not report individuals observed by sex.

\begin{tabular}{|c|c|c|c|c|c|}
\hline \multirow[b]{3}{*}{ Year } & \multirow[b]{3}{*}{ Males } & \multirow[b]{3}{*}{ Females } & \multirow{3}{*}{$\begin{array}{l}\text { Total adult } \\
\text { population } \\
\text { estimate }\end{array}$} & \multirow{3}{*}{$\begin{array}{r}\text { Percent of } \\
\text { adults } \\
\text { banded }\end{array}$} & \multirow{3}{*}{$\begin{array}{c}\text { Percent } \\
\text { males }\end{array}$} \\
\hline & & & & & \\
\hline & & & & & \\
\hline 1990 & - & - & 75 & 0.16 & - \\
\hline 1991 & - & - & 44 & 0.36 & - \\
\hline 1992 & - & - & 50 & 0.78 & - \\
\hline 1993 & 36 & 36 & 72 & 0.68 & 0.50 \\
\hline 1994 & 42 & 41 & 83 & 0.75 & 0.51 \\
\hline 1995 & 60 & 60 & 120 & 0.83 & 0.50 \\
\hline 1996 & 69 & 65 & 134 & 0.74 & 0.51 \\
\hline 1997 & 68 & 72 & 141 & 0.65 & 0.49 \\
\hline 1998 & 55 & 41 & 97 & 0.74 & 0.57 \\
\hline 1999 & 45 & 50 & 95 & 0.85 & 0.47 \\
\hline 2000 & 50 & 59 & 109 & 0.87 & 0.46 \\
\hline 2001 & 54 & 57 & 111 & 0.86 & 0.49 \\
\hline
\end{tabular}


E. P. Gaines et al.

Survival of Adult Snowy Plovers

Gaines - 29

\begin{tabular}{|c|c|c|c|c|c|}
\hline 2002 & 46 & 50 & 99 & 0.88 & 0.48 \\
\hline 2003 & 50 & 52 & 102 & 0.93 & 0.49 \\
\hline 2004 & 68 & 68 & 136 & 0.89 & 0.50 \\
\hline 2005 & 73 & 80 & 153 & 0.90 & 0.48 \\
\hline 2006 & 83 & 95 & 178 & 0.79 & 0.47 \\
\hline 2007 & 84 & 97 & 181 & 0.71 & 0.46 \\
\hline 2008 & 87 & 100 & 187 & 0.73 & 0.47 \\
\hline 2009 & 98 & 101 & 199 & 0.78 & 0.49 \\
\hline 2010 & 110 & 122 & 232 & 0.82 & 0.47 \\
\hline 2011 & 125 & 122 & 247 & 0.84 & 0.51 \\
\hline 2012 & 145 & 145 & 290 & 0.88 & 0.50 \\
\hline 2013 & 164 & 140 & 304 & 0.88 & 0.54 \\
\hline 2014 & 188 & 150 & 338 & 0.80 & 0.56 \\
\hline
\end{tabular}


E. P. Gaines et al.

Survival of Adult Snowy Plovers

Gaines - 30

Table 2. Number of predators removed at Snowy Plover nesting sites, 2002 - 2014.

\begin{tabular}{|c|c|c|c|c|c|c|c|c|c|c|}
\hline & & & & & & & & & & Great \\
\hline & & & Red & Striped & & Virginia & Feral & Gray & & Horned \\
\hline & Raven & Crow & fox & skunk & Raccoon $^{b}$ & opossum $^{\mathrm{C}}$ & $\mathrm{cat}^{\mathrm{d}}$ & fox ${ }^{e}$ & Coyote $^{f}$ & Owl ${ }^{g}$ \\
\hline $2002^{\mathrm{a}}$ & 12 & 14 & 6 & 5 & 12 & 1 & 1 & 2 & 0 & 0 \\
\hline $2003^{a}$ & 150 & 38 & 12 & 6 & 8 & 1 & 1 & 2 & 0 & 0 \\
\hline 2004 & 150 & 101 & 27 & 13 & 19 & 17 & 4 & 3 & 0 & 0 \\
\hline 2005 & 82 & 132 & 15 & 3 & 0 & 3 & 2 & 0 & 0 & 0 \\
\hline 2006 & 145 & 89 & 17 & 8 & 0 & 0 & 1 & 0 & 4 & 0 \\
\hline 2007 & 65 & 144 & 13 & 7 & 2 & 0 & 0 & 3 & 0 & 1 \\
\hline 2008 & 219 & 122 & 15 & 2 & 3 & 0 & 1 & 0 & 2 & 0 \\
\hline 2009 & 151 & 169 & 10 & 4 & 3 & 0 & 4 & 2 & 2 & 0 \\
\hline 2010 & 81 & 168 & 7 & 3 & 1 & 0 & 0 & 0 & 1 & 0 \\
\hline 2011 & 95 & 178 & 15 & 6 & 0 & 0 & 0 & 0 & 0 & 1 \\
\hline 2012 & 225 & 50 & 13 & 3 & 0 & 0 & 0 & 0 & 2 & 0 \\
\hline 2013 & 213 & 123 & 20 & 0 & 0 & 0 & 0 & 0 & 0 & 0 \\
\hline 2014 & 185 & 130 & 6 & 0 & 0 & 0 & 0 & 0 & 0 & 0 \\
\hline Total & 1773 & 1458 & 176 & 60 & 48 & 22 & 14 & 12 & 11 & 2 \\
\hline
\end{tabular}

${ }^{\text {a }}$ Predator removal occurred only at Coos Bay North Spit, Bandon, and New River in 2002 and 2003.

b Procyon lotor 
E. P. Gaines et al.

Survival of Adult Snowy Plovers

Gaines - 31

${ }^{\mathrm{c}}$ Didelphis virginiana

${ }^{\mathrm{d}}$ Felis catus

e Urocyon cinereoargenteus

${ }^{\mathrm{f}}$ Canis latrans

${ }^{g}$ Bubo virginianus 


\section{E. P. Gaines et al.}

Survival of Adult Snowy Plovers

Gaines - 32

Table 3. Model selection results for apparent survival $(\varphi)$ and detection probability $(p)$ of adult Snowy Plovers along the Oregon coast, 1990 - 2014. Models are ranked by ascending $\Delta \mathrm{QAIC}_{\mathrm{c}}$ values and shown with the model weight $\left(w_{i}\right)$, number of parameters $(K)$, and model deviance corrected for overdispersion $(\hat{c}=1.21)$. The $\mathrm{QAIC}_{\mathrm{c}}$ of the best model was 3099.65. Final parameters included sex (Sex), lethal predator management (PM), percent exclosure use (EX), wetter-than-average winter weather (Wet), and linear (T) and quadratic (TT) time trends. Only models with $\triangle \mathrm{QAIC}_{\mathrm{c}}$ less than 7 are shown.

\begin{tabular}{lcccc}
\hline Model & $\Delta$ QAICc & $w_{i}$ & $K$ & QDeviance \\
\hline$\varphi(\mathrm{T}) p(\mathrm{~T}+\mathrm{Sex})$ & 0.00 & 0.48 & 5 & 3089.63 \\
$\varphi(\mathrm{PM}) p(\mathrm{~T}+\mathrm{Sex})$ & 1.02 & 0.29 & 5 & 3090.65 \\
$\varphi(\mathrm{EX}) p(\mathrm{~T}+\mathrm{Sex})$ & 1.68 & 0.21 & 5 & 3091.31 \\
$\varphi(\mathrm{Wet}) p(\mathrm{~T}+\mathrm{Sex})$ & 6.03 & 0.02 & 5 & 3095.66 \\
\hline
\end{tabular}


E. P. Gaines et al.

Survival of Adult Snowy Plovers

Gaines - 33

\section{LIST OF FIGURES}

Fig. 1. Nesting sites of Snowy Plovers in Oregon, 1990-2014. Black dots include all regularly occupied nesting habitat during the study period. The airplane indicates the location of North Bend Regional Airport weather station. Gray shaded line in inset map shows the extent of the Pacific Coast population distribution. The black box indicates map extent.

Fig. 2. Effect of exclosure use on apparent survival ( $\pm 95 \%$ CI) of adult Snowy Plovers as estimated by model $\varphi(\mathrm{EX}) p(\mathrm{~T}+\mathrm{Sex})$ in Oregon, $1990-2014$. 
E. P. Gaines et al.

Survival of Adult Snowy Plovers

Gaines - 34

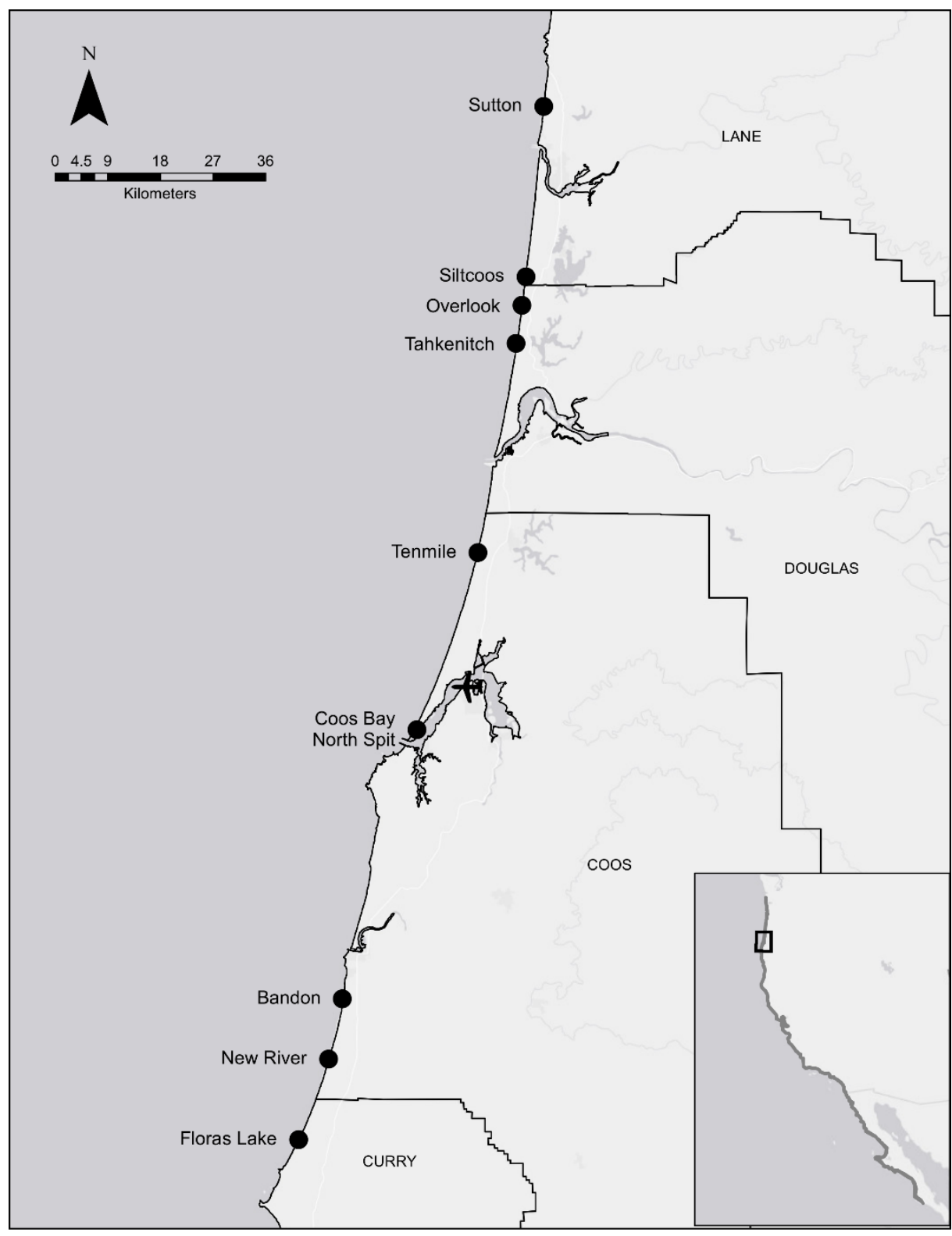

Fig. 1. Nesting sites of Snowy Plovers in Oregon, 1990-2014. Black dots include all regularly occupied nesting habitat during the study period. The airplane indicates the location of North Bend Regional Airport weather station. Gray shaded line in inset map shows the extent of the Pacific Coast population distribution. The black box indicates map extent. 


\section{E. P. Gaines et al.}

Survival of Adult Snowy Plovers

Gaines - 35

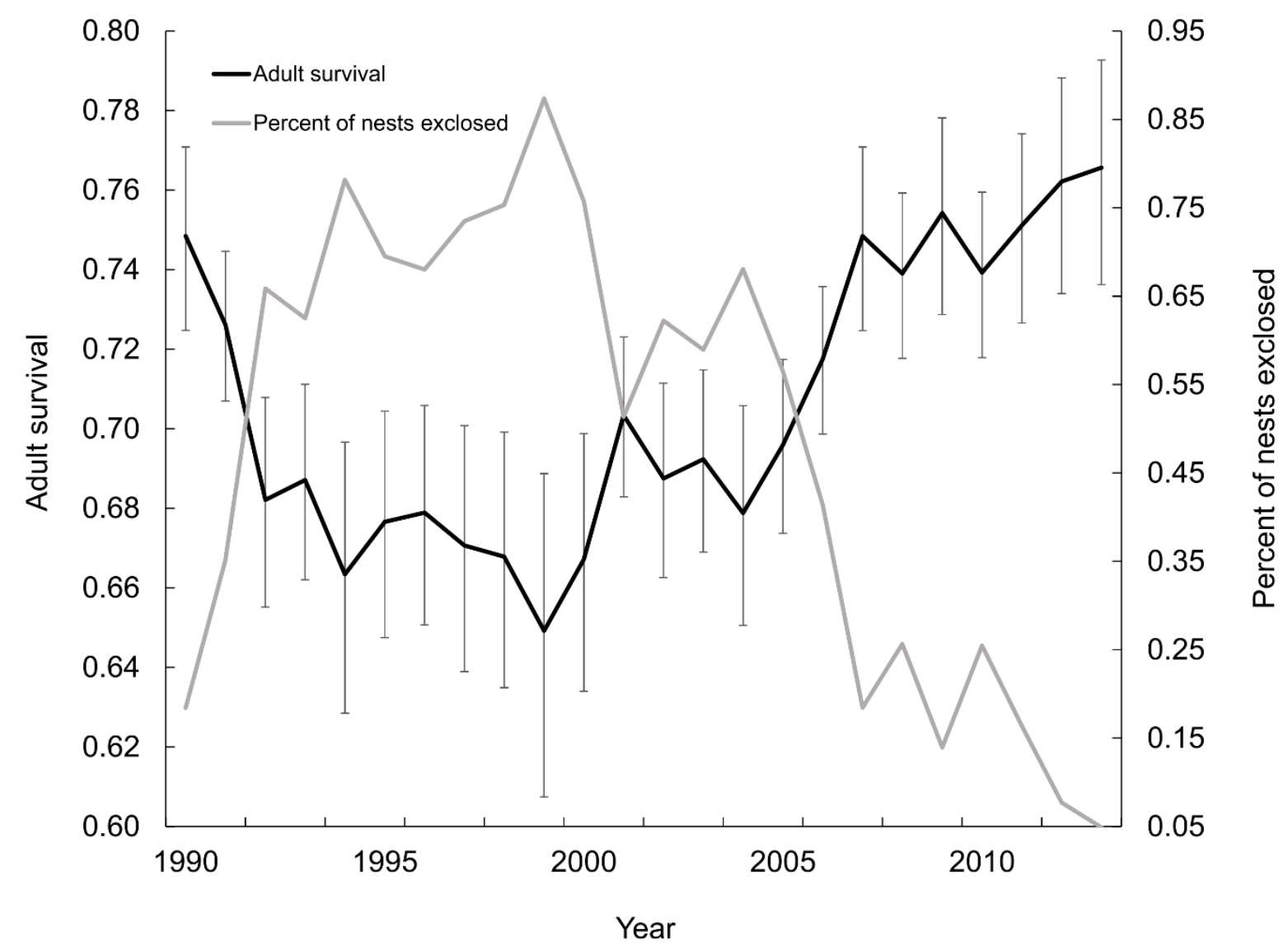

Fig. 2. Effect of exclosure use on apparent survival ( $\pm 95 \%$ CI) of adult Snowy Plovers as estimated by model $\varphi(\mathrm{EX}) p(\mathrm{~T}+\mathrm{Sex})$ in Oregon, $1990-2014$. 